\title{
Langerhans' cells are depleted in chronic graft versus host disease
}

Sélim Aractingi, Eliane Gluckman, Marie Christine Dauge-Geffroy, Caroline Le Goué, Antoine Flahaut, Louis Dubertret, Edgardo Carosella

\begin{abstract}
Aims-To measure Langerhans' cells in skin of patients treated by bone marrow transplantation who developed chronic graft versus host disease (GvHD); to determine whether the reduction in Langerhans' cells resulted directly from the GvHD or from other factors, such as the immunosuppressive regimens used in bone marrow transplant patients.

Patients and methods-Lesional and nonlesional skin specimens from nine patients with lichen planus-like lesions and three patients with sclerodermoid lesions were studied. Control skin specimens were taken from three patients undergoing breast reduction surgery. The number of Langerhans' cells $/ \mathrm{mm}^{2}$ and the area of Langerhans' cells as a percentage of total epidermis were measured by counting cells labelled with antihuman CD1a.

Results-A significant reduction in Langerhans' cell area and number were found in specimens with lesions (area 3.5\%; number $507 / \mathrm{mm}^{2}$ ) compared with specimens without lesions $\left(8.42 \% ; 2375 / \mathrm{mm}^{2}\right)$. In contrast, Langerhans' cell area and number in skin without lesions were similar to controls $\left(10.26 \% ; 2968 / \mathrm{mm}^{2}\right)$.

Conclusions-Langerhans' cells were significantly reduced in skin with lesions of chronic GvHD but not in skin without lesions from the same patient, suggesting that the reduction is a direct consequence of GvHD and not linked to immunosuppressive drugs or late effects of conditioning regimens. In long term bone marrow transplant recipients, Langerhans' cells are derived mainly from the donor cells; therefore, this result suggests the occurrence of autoreactive phenomenon in chronic GvHD.

(F Clin Pathol 1997;50:305-309)
\end{abstract}

Keywords: Graft versus host disease; Langerhans' cells; bone marrow transplantation

d'Epidemiologie,

Hôpital Tenon, 4, rue

de la Chine, 75020

Paris, France

A Flahaut

Correspondence to:

Sélim Aractingi, Service de recherche en

hémato-immunologie-CEA,

Hôpital St Louis, Centre

Hayem, 1 , avenue Claude

Vellefaux, 75475 Paris,

France.

Accepted for publication

2 December 1996

Langerhans' cells are powerful antigen presenting cells present in skin and epithelia. ${ }^{1}$ After bone marrow transplantation there is a reduction in the number of epidermal Langerhans' cell, ${ }^{23}$ the nadir occurring during the first month, followed by a slow repopulation. ${ }^{24}$ Langerhans' cells originate from bone marrow, therefore, this reduction is at least in part secondary to the conditioning regimen of bone marrow transplantation. However, several authors have shown that the reduction of Langer- hans' cells was greater in recipients with acute graft versus host disease (GvHD) compared with those without acute $\mathrm{GvHD},{ }^{2-10}$ raising the hypothesis that Langerhans' cells may be targets of this reaction. Chronic GvHD is a disabling complication occurring in $25-40 \%$ of bone marrow transplant recipients, the skin being its principal target organ. ${ }^{11}$ Few studies have focused on Langerhans' cells during this disease and their results are controversial. ${ }^{4}{ }^{12-14}$ To determine the status of these cells in chronic GvHD, we quantitatively analysed Langerhans' cells.

\section{Patients and methods}

Skin biopsies from patients treated with allogenic bone marrow transplants for more than three months were taken when patients presented typical lichen planus-like (nine patients) or sclerodermoid (three patients) lesions. After informed consent, biopsies of skin with and without lesions were performed. Non-lesional specimens were taken from the same anatomical site as the lesions, but on the other side of the body. All patients had histopathological confirmation of the clinical diagnosis. Control biopsies were taken from normal skin of three patients who had breast reduction surgery. Each specimen was cut in two parts; one was placed in formalin and processed for light microscopy, the other was snap-frozen in liquid nitrogen. Patients were included in whom blind histopathological examination found classical features of lichen planus-like or sclerodermoid GvHD. ${ }^{15}$

IMMUNOHISTOCHEMISTRY AND MORPHOMETRY Sections $(4-6 \mu \mathrm{m})$ were cut from the frozen specimens. They were fixed in cold acetone, and incubated for 30 minutes at room temperature with normal serum from the same origin as the second antibody (to block non-specific binding). Anti-human CD1a monoclonal antibody (Immunotech, France) was added during this time. The sections were washed with phosphate buffered saline, incubated with a biotin conjugated antimouse antibody, and revelation was done with AEC.
Number of Langerhans' cells

The number of CDla labelled cells $/ \mathrm{mm}^{2}$ of epidermis was evaluated with an ocular grid. Immunostained cells were counted on 10 consecutive fields at $\times 400$ magnification, that is, a $2.8 \mathrm{~mm}$ long epidermis sample for each case.

Surface area of CD1 a stained cells Quantitative analysis of specimens was carried out using a computer assisted quantification 
Table 1 Data from patients with lichen planus and sclerodermoid graft versus host disease lesions

\begin{tabular}{llllll}
\hline Lesion & Sex & Age & $\begin{array}{l}\text { Haematological } \\
\text { disease }\end{array}$ & $\begin{array}{l}\text { Conditioning } \\
\text { regimen }\end{array}$ & $\begin{array}{l}\text { Time of biopsy } \\
\text { (months after } \\
\text { BMT) }\end{array}$ \\
\hline Lichen & F & 51 & AML & Cy-TBI & 52 \\
Lichen & M & 42 & CML & Cy-TBI & 6 \\
Lichen & F & 39 & ALL & cytA-MelphTBI & 36 \\
Lichen & M & 16 & AML & Cy-TBI & 24 \\
Lichen & M & 45 & NHL & Cy-TBI Eto & 8 \\
Lichen & M & 24 & AML & Cy-Bu & 15 \\
Lichen & M & 38 & CML & TBI-Cy CCNU & 12 \\
Lichen & M & 41 & MDS & Cy-TBI Eto & 6 \\
Lichen & M & 41 & AML & Cy-Bu & 42 \\
Sclerodermoid & F & 22 & CML & Cy-Bu Eto & 15 \\
Sclerodermoid & M & 35 & CML & Cy-TBI & 36 \\
Sclerodermoid & F & 40 & AML & Cy-Bu & 70 \\
\hline
\end{tabular}

BMT, bone marrow transplantation; $\mathrm{Cy}$, cyclophosphamide; Bu, busulfan, Eto, etoposide; CytA cytarabine; Melph, melphalan; TBI, total body irradiation; CCNU, carmustine; AML, acute myelogenous leukaemia; MDS, myelodysplastic syndrome; CML, chronic myelogenous leukaemia, ALL, acute lymphoblastic leukaemia, NHL, non-Hodgkin's lymphoma.

technique. ${ }^{16}$ Images of the CD1a immunostained biopsy specimens were conveyed through a Leitz photomicroscope, including an IEC $800 \mathrm{CC}$ colour video camera, to a computer with a analogue-to-digital converter (Cyclope, Système Sud, France), which displayed this signal in grey scale (256 levels) to a video monitor $(738 \times 511$ pixels $)$ as well as directly to a control video screen. The sections were studied at $\times 250$ magnification ( 1 pixel $=0.439 \mu \mathrm{m}$ ). For each session, controls were performed with a reference section to obtain the best adjustment for glare and a shading correction providing good reproducibility of values in each case. Measurements of Langerhans' cell surface area was made on the whole thickness of the skin epidermis within a $1 \mathrm{~mm}$ long sample. These values, as well as the total epidermal area, were determined by binarisation and calculated with a computerised morphometric software (Esilab V3-0, Desi Inc, Paris, France). The Langerhans' cell surface area was expressed as the percentage of the whole epidermal area.

\section{STATISTICAL ANALYSIS}

Data were expressed as median (range) values. The comparisons between specimens with and without lesions were by the signed Wilcoxon

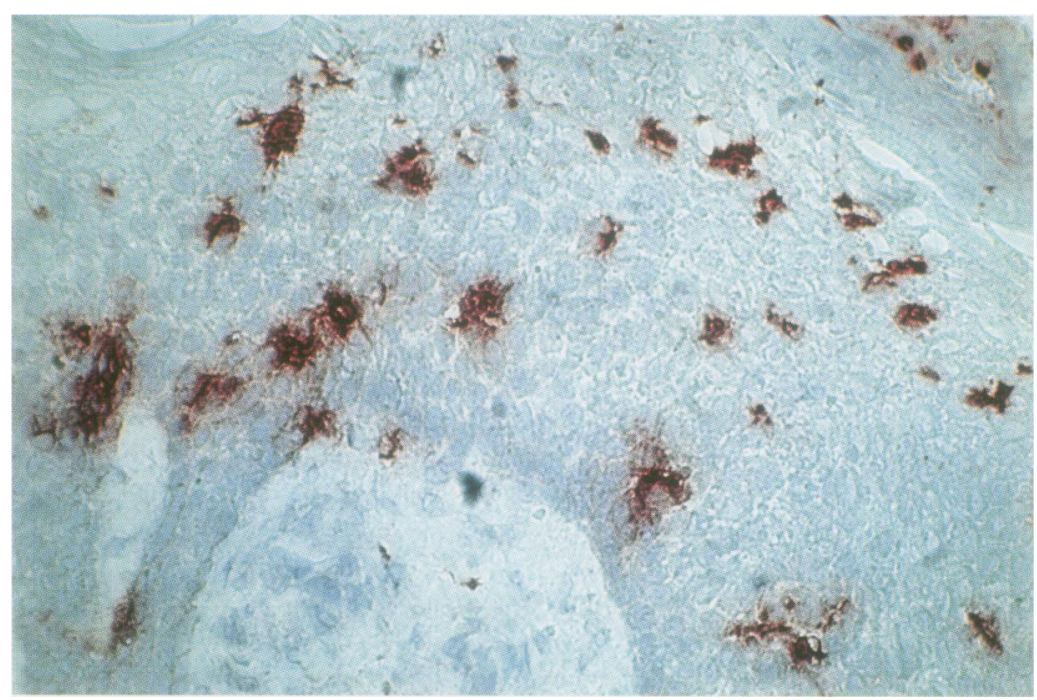

Figure 1 CD1 a labelled dendritic cells in the epidermis of a patient with GvHD (original magnification $\times 250$ ).
Table 2 Langerhans' cell area in chronic graft versus host disease and controls (\% of epidermal area)

\begin{tabular}{lcl}
\hline Controls & Without lesions & With lesions \\
\hline 8.6 & 7.5 & 1.7 \\
7.3 & 11.1 & 2.2 \\
8.4 & 11.8 & 4.4 \\
& 10.2 & 3.8 \\
& 6.1 & 3.3 \\
& 20.6 & 4.4 \\
& & 8.4 \\
& 13.0 & 2.7 \\
& 6.3 & 5.3 \\
& 2.1 & 0.7 \\
Median & 11.4 & 0.4 \\
8.421 & 7.5 & 5.6 \\
\hline
\end{tabular}

Table 3 Langerhans' cell number in chronic graft versus host disease and controls (per $\mathrm{mm}^{2}$ epidermis)

\begin{tabular}{lll}
\hline Controls & Without lesions & With lesions \\
\hline 3026 & 2375 & 653 \\
2689 & 2101 & 88 \\
2968 & 2880 & 130 \\
& 1444 & 730 \\
& 1104 & 569 \\
& 1529 & 446 \\
& 5482 & 2033 \\
& 2789 & 41 \\
& 726 & 1599 \\
& 2830 & 38 \\
Median & 3187 & 280 \\
2968 & 2375 & 2347 \\
\hline
\end{tabular}

test (two-sided). Statistical significance was $p \leqslant 0.05$. Specimens without lesions and control specimens were compared using the Mann and Whitney (bilateral) test.

\section{Results}

The details of the 12 patients are shown in table 1 .

SKIN WITHOUT LESIONS

Immunohistochemistry showed dendritic CD1 a labelled cells in the epidermis of patients with chronic GvHD (fig 1) in specimens with and without lesions. The CD1a epidermal labelled area was $8.421 \%(7.397-8.689)$ in control specimens and $10.264 \%$ (2.17920.686) in specimens without lesions from GvHD patients $(p=0.25)$ (table 2). The Langerhans' cell numbers in skin without lesions from chronic GvHD patients and controls were $2375 / \mathrm{mm}^{2}(726-5482)$ and $2968 / \mathrm{mm}^{2}$ (2689-3026), respectively (not significant) (table 3 ).

\section{SKIN WITH LESIONS}

The CDla labelled area in the epidermis of skin with lesions from patients with chronic GvHD was $3.5 \%(0.492-8.469)$. This area was significantly reduced compared to the skin without lesions $(10.264 \%)$ ( $p<0,003)$. Similarly, Langerhans' cell numbers were reduced in skin with lesions $\left(507 / \mathrm{mm}^{2}(38-2347)\right)$ compared with skin without lesions (2375/ $\left.\mathrm{mm}^{2}\right) \quad(\mathrm{p}<0.03)$. Dermal dendritic CD1a positive cells were very scarce in skin with lesions. 


\section{Discussion}

The reduction in the CDla labelled areas and the CDla cell counts found in the diseased skin specimens of chronic GvHD indicates a genuine depletion in Langerhans' cells. CD1 a labelling of epidermal dendritic cells is highly specific for Langerhans' cells and, in contrast with class II expression, it is not variable in the epidermis. ${ }^{17} 18$ The differences between patients was expected because of the differences in disease severity and anatomical sites biopsied. Furthermore, Langerhans' cell area and cell counts were consistently lower in the diseased skin of each patient compared with skin without lesions. The Langerhans' cell area was analysed using a quantitative and reproducible method. ${ }^{16}$ Finally, non-parametrical tests, which do not involve any assumption on the distribution of the studied variables, disclosed a very significant reduction of both Langerhans' cell area and cell counts.

Pathogenesis of chronic GvHD is not well understood. ${ }^{11}$ The presence of anti-host specific $T$ cells has been found in circulating cells $^{19-21}$ and in skin biopsies ${ }^{22}$ of patients with chronic GvHD, demonstrating the presence of allogenic recognition in this disease. However, if anti-host mechanisms were the sole implication in this reaction, the multiple differences between clinical manifestations of chronic and acute GvHD, which results only from anti-host recognition, would remain unexplained. In the same way, the frequent detection of autoantibodies ${ }^{2324}$ as well as the thrombocytopenia and lymphocytopenia of donor cell lineage ${ }^{25}{ }^{26}$ in chronic GvHD recipients cannot be explained by a pure alloreactive mechanism. During acute GvHD in mice, thymic damage has been demonstrated followed by the development of self reactive $\mathrm{T}$ cell clones. ${ }^{27}{ }^{28}$ The hypothesis that chronic GvHD in humans is associated with autoreactive lymphocytes (similar to that demonstrated in mice $^{29}$ ) has been proposed by several authors. ${ }^{11} 3031$

The evolution of Langerhans' cells after bone marrow transplantation has been studied by counting labelled cells with ocular grids at different times. After transplantation, there is a constant reduction of Langerhans' cells, even in the absence of GvHD, indicating that the conditioning regimen alone leads to a decrease in epidermal Langerhans' cells. ${ }^{2-4}$ If irradiation is not part of the conditioning regimen, a similar decrease in Langerhans' cells is found. A nadir in the epidermal Langerhans' cells number has been observed at day 11 in humans and day 14 in mice. ${ }^{2}{ }^{3}$ Thereafter, the number of Langerhans' cells increases and normal counts occur between day 100 and day $315 .^{24}$ The epidermal repopulation of Langerhans' cells is mainly or exclusively with cells from donor origin. ${ }^{32}{ }^{33}$ Of note, the reduction in Langerhans' cells is associated with a reduced ability of the epidermis to present antigens. ${ }^{8}$

Table 4 Studies of Langerhans' cells (LC) in bone marrow transplant (BMT) recipients

\begin{tabular}{|c|c|c|c|c|}
\hline Reference & Subjects & Methods & Results & $\begin{array}{l}\text { Comparison of patients with and } \\
\text { without GvHD }\end{array}$ \\
\hline Gomes et al $1982^{12}$ & Humans ( 3 patients) & Counting OKT6+ cells & $\begin{array}{l}\text { Decrease of LC in chronic GvHD } \\
\text { compared with normal skin No dermal } \\
\text { OKT6+ in dendritic cells }\end{array}$ & No \\
\hline Suitters et al $1983^{3}$ & Rats (2 to 7 ) & $\begin{array}{l}\text { Counting } 1 \mathrm{a}+\text { dendritic cells } \\
\text { in ears }\end{array}$ & $\begin{array}{l}\text { LC counts after irradiation } 46 \% \text { less } \\
\text { than before }\end{array}$ & $\begin{array}{l}\text { In mice with acute GvHD } \\
\text { complete absence of LC }\end{array}$ \\
\hline Perreault et al $1984^{2}$ & Humans (19 patients) & Counting OKT $6+$ cells & $\begin{array}{l}\text { Kinetics study with biopsy before and } \\
\text { after BMT } \\
\text {-nadir day } 11 \\
\text {-normal count reached between day } 120 \\
\text { and day } 135\end{array}$ & $\begin{array}{l}\text { Greater reduction in grades II-IV } \\
\text { acute GvHD compared with grades } \\
0 \text {-II }\end{array}$ \\
\hline Kay et al $1984^{5}$ & Humans ( 9 patients) & Counting OKT6+ cells & $\begin{array}{l}\text { Decrease after BMT compared with } \\
\text { normal controls }\end{array}$ & $\begin{array}{l}4 \mathrm{LC} / 100 \mathrm{KC} \text { in acute } \mathrm{GvHD} \\
6 \mathrm{LC} / 100 \mathrm{KC} \text { in controls }\end{array}$ \\
\hline Sloane et al $1984^{34}$ & Humans (28 patients) & Counting Nal $34+$ cells & $\begin{array}{l}\text { Decrease after BMT compared with } \\
\text { before }\end{array}$ & No \\
\hline Murphy et al $1985^{35}$ & Humans (15 patients) & Counting OKT6+ cells & $\begin{array}{l}\text { Decrease during weeks } 1-4 \text { compared } \\
\text { with before BMT }\end{array}$ & $\begin{array}{l}\text { No difference in LC decrease in } \\
\text { acute GvHD+ versus GvHD- } \\
\text {-slower repopulation in acute } \\
\text { GvHD+ }\end{array}$ \\
\hline Dreno et al $1986^{7}$ & Humans (14 patients) & Counting IOT6+ cells & $\begin{array}{l}\text { Decrease at days } 14,21,28 \text { compared } \\
\text { with normal skin }\end{array}$ & $\begin{array}{l}2-3 \mathrm{LC} / \text { field in acute GvHD- } \\
0-2 \mathrm{LC} / \text { field in acute GvHD+ }\end{array}$ \\
\hline Atkinson et al $1986^{13}$ & Humans (36 patients) & Counting OKT6+ cells & Decrease after BMT & $\begin{array}{l}\text { No difference between epidermal } \\
\text { LC in chronic GvHD+ versus } \\
\text { chronic GvHD- } \\
\text { deep reduction in dendritic dermal } \\
\text { cells in chronic GvHD+ }\end{array}$ \\
\hline Breatnach et al $1986^{8}$ & Mice & Counting $1 \mathrm{a}+$ dendritic cells & Decrease after BMT & $\begin{array}{l}\text { Greater decrease of LC in acute } \\
\text { GvHD patients }\end{array}$ \\
\hline Elliot et al $1988^{9}$ & Humans (31 patients) & Counting $\mathrm{Na} 134+$ cells & $\begin{array}{l}\text { Decrease after BMT compared with } \\
\text { before }\end{array}$ & $\begin{array}{l}\text { Greater decrease of LC in acute } \\
\text { GvHD patients }\end{array}$ \\
\hline Paller et al $1988^{36}$ & Humans (23 patients) & Counting OKT6+ cells & Decrease compared with normal skin & $\begin{array}{l}\text { No correlation of LC depletion and } \\
\text { acute GvHD LC depletion on } \\
\text { chronic GvHD }\end{array}$ \\
\hline Volc Platzer et al $1988^{4}$ & Humans (64 patients) & Counting OKT6+ cells & $\begin{array}{l}\text { Decrease compared with before BMT; } \\
\text { increase to normal by day } 100\end{array}$ & $\begin{array}{l}\text { No correlation of LC depletion and } \\
\text { acute GvHD LC depletion on } \\
\text { chronic GvHD }\end{array}$ \\
\hline $\begin{array}{l}\text { Sviland et al } 1991^{10} \\
\text { Mattsson et al } 1992^{14}\end{array}$ & $\begin{array}{l}\text { Humans ( } 12 \text { patients; } 3 \\
\text { lichen planus) }\end{array}$ & $\begin{array}{l}\text { Counting OKT } 6+\text { cells } \\
\text { Counting CD1a+ cells in } \\
\text { oral biopsies }\end{array}$ & $\begin{array}{l}\text { LC number returned to normal after } 6 \\
\text { months }\end{array}$ & $\begin{array}{l}\text { Greater decrease of LC in acute } \\
\text { GvHD patients } \\
\text { Greater decrease of LC in chronic } \\
\text { GvHD patients compared with } \\
\text { lichen planus }\end{array}$ \\
\hline
\end{tabular}


The influence of acute GvHD on epidermal Langerhans' cells has been evaluated in several studies (table 4). Most studies in humans indicate that patients with acute GvHD have a greater reduction in Langerhans' cell count than recipients without GvHD. ${ }^{23-10}$ Some authors did not find any difference between patients with or without acute GvHD, ${ }^{45}{ }^{36}$ but they found that Langerhans' cell repopulation was slower in patients with GvHD. ${ }^{35}$ In animals, Langerhans' cell reduction was greater if there was acute GvHD. ${ }^{38}$ These results strongly suggest that Langerhans' cells may be a target of the acute GvHD reaction. However, the comparison was made between groups with or without GvHD, therefore, the role of immunosuppressive drugs in the depletion of Langerhans' cells cannot be excluded. ${ }^{37}$

The present study compared skin with and without lesions from the same patient. As skin without lesions has been exposed to the same treatments as that with lesions, the only difference is GvHD. The role of the prior haematological disease, the conditioning regimen, and the immunosuppressive drugs cannot be responsible for the reduction in Langerhans' cells, as skin without lesions did not differ from control skin. However, because of the small number of normal controls, a true difference between skin without lesions from patients with GvHD and normal skin cannot be ruled out and further analysis is needed. Furthermore, there is possibly greater variation in the surface areas than in the cell numbers. Further analysis is therefore needed with more cases. Our results are, however, in accordance with other groups. ${ }^{421433}$ Of note, in one study, epidermal Langerhans' cell counts were not decreased in chronic GvHD, but dermal dendritic cells were significantly reduced. ${ }^{13}$

A decrease in epidermal Langerhans' cells does not always occur in inflammatory conditions. Langerhans' cell counts were normal or increased in disorders such as alopecia areata, vitiligo, bullous pemphigoid, pemphigus, $\mathrm{T}$ cell lymphoma, and Pityriasis rosea. ${ }^{38-42}$ In contrast, studies in lichen planus and lupus erythematosus, autoimmune diseases close to chronic GvHD, have shown a reduction in Langerhans' cells. ${ }^{12}{ }^{43}$ Langerhans' cells in grafted patients originate mainly from the donor cells. ${ }^{32}{ }^{33}$ The reduction in epidermal Langerhans' cells in chronic GvHD lesions is a further argument for the involvement of autoimmune phenomenon in chronic GvHD.

This work was supported in part by Etablissement Français des Greffes, Ligue contre le Cancer and ARTM.

1 Silberberg-Sinakin I, Gigli I, Baer RL, Thorbecke GJ. Langerhans cells: role in contact hypersensitivity and relationship to lymphoid dendritic cells and to macrophages. Immunol Rev 1980;53:203-32.

2 Perreault C, Pelletier M, Landry D, Gyger M. Study of Langerhans cells after allogeneic bone marrow transplantation. Blood 1984;63:807-11.

3 Suitters AJ, Lampert IA. The loss of Ia+ Langerhans cells during graft versus host disease in rats. Transplantation 1983;36:540-6.

4 Volc-Platzer B, Rappersberger K, Mosberger I, Hinterbreger W, Emminger-Schmidmeier W, Radaszkiewicz T, et al. Sequential immunohistologic analysis of the skin following Sequential immunohistologic analysis of the skin following
allogeneic bone marrow transplantation. $\mathcal{F}$ Invest Dermatol 1988;91:162-8.
5 Kay VN, Neumann PM, Kersey J, Goltz RW, Baldridge BD, Michael MF, et al. Identity of immune cells in graft versus host disease of the skin. Am $f$ Pathol 1984;116:436-40.

6 Lever R, Turbitt M, Mackie R, Hann I, Gibson B, Burnett Lever R, Turbitt M, Mackie R, Hann I, Gibson B, Burnett
A, et al. A prospective study of the histological changes in the skin in patients receiving bone marrow transplants. $\mathrm{Br} f$ Dermatol 1986;114:161-70.

7 Dreno B, Milpied N, Harousseau JL, Stalder JF, Bureau B, Milpied $\mathrm{M}$, et al. Cutaneous immunological studies in diagnosis of acute graft versus host disease. $\mathrm{Br} \mathcal{F}$ Dermatol 1986;114:7-15.

8 Breatnach SM, Shimada S, Kovac Z, Katz S. Immunologic aspects of acute cutaneous graft versus host disease: decreased density and antigen presenting function of Iat Langerhans cells and absent presenting capacity of Iat Langerhans cells and absent presenting capacity

9 Elliott CJ, Sloane JP, Pallett CD, Sanderson KV. Cutaneous leucocyte composition after human allogeneic bone marrow transplantation: relationship to marrow purging, histology and clinical rash. Histopathology 1988;12:1-16.

10 Sviland L, Pearson A, Green M, Baker B, Eastham E, Reid $\mathrm{M}$, et al. Immunopathology of early graft versus host disease-a prospective study of skin, rectum and peripheral blood in allogeneic and autologous bone marrow transplant recipients. Transplantation 1991;52:1029-36.

11 Atkinson K. Pathogenesis of human chronic graft-vs-host disease. In: Burakoff SJ, Deeg HJ, Ferrara J, Atkinson K, eds. Hematology. Vol 12. New York: Marcel Dekker Inc, 1990:615-23.

12 Gomes M, Schmitt D, Souteyrand P, Ohrt C, Brochier J, Thivolet J. Lichen planus and chronic graft versus host reaction. In situ identification of immunocompetent cel phenotypes. F Cutan Pathol 1982;9:249-57.

13 Atkinson K, Munro V, Vasak E, Biggs J. Mononuclear cell subpopulations in the skin defined by monoclonal antibodies after HLA identical sibling marrow transplantation. $B r \mathcal{F}$ Dermatol 1986;114:145-60.

14 Mattsson T, Sundvqist KG, Heimdahl A, Dahllof G, Ljungman $P$, Ringden O. A comparative immunological analysis man P, Ringden O. A comparative immunological analysis of the oral mucosa in chronic graft versus host dis
oral lichen planus. Arch Oral Biol 1992;7:539-47.

15 Shulman HM, Sullivan KM, Weiden PL MacDonald GB Striker G, Sale GE, et al. Chronic graft-versus-host syndrome in man. A long-term clinicopathologic study of 20 Seattle patients. $A m$ F Med 1980;69:204-17.

16 Gervaz E, Dauge Geffroy MC, Sobhani I, Vissuzaine C, Mignon M, Benhamou G, et al. Quantitative analysis of the immune cells in the anal mucosa. Pathol Res Pract 1995;191:1067-71.

17 Van de Rijn M, Lerch PG, Bronstein BR, Knowles RW, Bhan AK, Terhorst RC. Human cutaneous dendritic cells express 2 glycoproteins T6 and M241 which are biochemically identical to those found on cortical thymocytes. Human Immunol 1984;9:201-10

18 Boumsell L. T1 cluster report; CD1. In: Knapp W, Gilks WR, Rieber EP, Schmidt RE, Stein $\mathrm{H}$, von derm Borne AEGKr, eds. Leucocyte typing IV. Oxford: Oxford University Press, 1989:251-4.

19 Tsoi MS, Storb R, Dobbs S, Medill L, Thomas ED. Cell mediated immunity to non-HLA antigens of the host by donor lymphocytes in patients with chronic graft-versusdonor lymphocytes in patients with chronic

20 Goulmy E, Blockland E, Gratama JW, Zwaan FE, van Rood $\mathrm{JJ}$. Host directed cytotoxic activity in bone marrow grafted patients. Transplant Proceed 1985;17:725-6.

21 Bunjes D, Theobald M, Nierle T, Arnold R, Heimpel H. Presence of host specific IL2 secreting $T$ helper cell precursors correlates closely with active primary and secondary chronic graft versus host disease. Bone Marrow Transplant 1995;15:727-32.

22 Kasten Sportes CM, Masset M, Varrin F, Devergie A Gluckman E. Phenotype and function of T-lymphocyte the skin during graft-versus-host disease following allogenic skin during graft-versus-host disease following allogenic
bone-marrow transplantation. Transplantation 1989;47: $621-4$.

23 Rouquette -Gally AM, Boyeldieu D, Gluckman E, Abuaf N, Combrisson A. Autoimmunity in 28 patients after allogeneic bone marrow transplantation: comparison with Sjogren's syndrome and scleroderma. Br $\mathcal{F}$ Haematol 1986; 66:45-7.

24 Wesierska-Gadek J, Penner E, Hitchman E, Kier P, Sauermann G. Nucleolar proteins B23 and C23 as target antigens in chronic graft versus host disease. Blood 1992;79: 1081-6.

25 Graze PR, Gale RP. Chronic graft-versus-host disease: a syndrome of disordered immunity. Am 7 Med 1979;66: 611-20.

26 Anasetti C, Rybka W, Sullivan KM, Banaji M, Slichter SJ Graft-v-host disease is associated with autoimmune-like thrombocytopenia. Blood 1989;3:1054-8.

27 Fukushi N, Arase H, Wang B, Ogasawara K, Gotohida T, Good $R$, Onoe $K$. Thymus: a direct tissue in graft versus host reaction after allogeneic bone marrow transplantation that results in abrogation of induction of self tolerance. Proc Natl Acad Sci 1990;87:6301-5.

28 Holländer GA, Widmer BA, Burakoff SJ. Loss of normal thymic repertoire selection and persistence of autoreactive $T$ cells in graft versus host disease. 7 Immunol 1994;152 1069-17.

29 Parkman R. Clonal analysis of murine graft versus host disease. F Immunol 1986;136:3543-8.

30 Parkman R. Chronic graft versus host: an alternative hypothesis. Immunol Today 1989;10:362-3. 
31 Ferrara JLM, Deeg HJ. Graft-versus-host disease. $N$ Engl $\mathcal{F}$ Med 1991;324:667-74.

32 Katz SI, Tamaki K, Sachs DH. Epidermal Langerhans cells are derived from cells originating in bone marrow. Nature 1979;282:324-6.

33 Volc Platzer B, Stingl G, Wolff K, Hinterderg W, Schnedl G. Cytogenetic identification of allogeneic epidermal Langerhans cells in a bone marrow recipient. $N$ Engl f Med 1984 310:1123-4.

34 Sloane JP, Thomas JA, Imrie SF, Easton DF, Powless RI Morphological and immunohistological changes in the skin in allogeneic bone marrow recipients. F Clin Pathol 1984;37:919-30.

35 Murphy G, Merot Y, Tong AK, Smith B, Mihm M. Depletion and repopulation of epidermal dendritic cells after allogeneic bone marrow transplantion in humans. $\mathcal{F}$ Invest allogeneic bone marrow tran

36 Paller A, Nelson A, Steffen L, Gottschalk L, Kaizer H. T lymphocyte subsets in the lesional skin of allogeneic and autologous bone marrow transplant patients. Arch Dermatol 1988;124:1795-801.
37 Belsitto DV, Flotte TJ, Lim HW, Baer RL, Thorbecke GJ Gigli I. Effect of glucocorticosteroids on epidermal Langerhans cells. $\mathcal{F}$ Exp Med 1982;155:291-5.

38 Claudy AL, Rouchouse B. Langerhans cell and vitiligo: quantitative study of T6 and HLA-DR expressing cells. Acta Derm Venereol 1984;64:334-6.

39 Nestor MS, Cochran AJ, Razzaque Ahmed A. Mononuclear cell infiltrate in bullous disease. $\mathcal{F}$ Invest Dermatol 1987;88 172-5.

40 Shiohara T, Moriya N, Saizawa KM, Nagashima M. Role of Langerhans cells in the epidermotropism of T cells. Arch Dermatol Res 1988;280:33-8.

41 Wiesner-Menzel L, Happle R. Intrabulbar and peribulbar accumulation of dendritic OKT6 positive cells in alopecia accumulation of dendritic OKT6 positive

42 Takaki Y, Mizayaki H. Cytologic degeneration of keratinocytes of keratinocytes adjacent to Langerhans cells in pityrasis rosea. Acta Dermatol Venereol 1979;59:7-13.

43 Sontheimer RD, Bergstresser PR. Epidermal Langerhan cell involvement in lupus erythematosus. $\mathcal{F}$ Invest Dermatol 1982;79:237-24 